\title{
Sequence-selective recognition of double-stranded RNA and enhanced cellular uptake of cationic nucleobase and backbone-modified peptide nucleic acids
}

\author{
DZIYANA HNEDZKO, ${ }^{1}$ DENNIS W. MCGEE, ${ }^{2}$ YANNIS A. KARAMITAS, ${ }^{1}$ and ERIKS ROZNERS ${ }^{1}$ \\ ${ }^{1}$ Department of Chemistry, ${ }^{2}$ Department of Biological Sciences, Binghamton University, State University of New York, Binghamton, \\ New York 13902, USA
}

\begin{abstract}
Sequence-selective recognition of complex RNAs in live cells could find broad applications in biology, biomedical research, and biotechnology. However, specific recognition of structured RNA is challenging, and generally applicable and effective methods are lacking. Recently, we found that peptide nucleic acids (PNAs) were unusually well-suited ligands for recognition of doublestranded RNAs. Herein, we report that 2-aminopyridine $(M)$ modified PNAs and their conjugates with lysine and arginine tripeptides form strong $\left(K_{\mathrm{a}}=9.4\right.$ to $\left.17 \times 10^{7} \mathrm{M}^{-1}\right)$ and sequence-selective triple helices with RNA hairpins at physiological pH and salt concentration. The affinity of PNA-peptide conjugates for the matched RNA hairpins was unusually high compared to the much lower affinity for DNA hairpins of the same sequence $\left(K_{\mathrm{a}}=0.05\right.$ to $\left.1.1 \times 10^{7} \mathrm{M}^{-1}\right)$. The binding of double-stranded RNA by M-modified PNA-peptide conjugates was a relatively fast process $\left(k_{\text {on }}=2.9 \times 10^{4} \mathrm{M}^{-1} \mathrm{sec}^{-1}\right) \mathrm{compared} \mathrm{to}$ the notoriously slow triple helix formation by oligodeoxynucleotides $\left(k_{\mathrm{on}} \sim 10^{3} \mathrm{M}^{-1} \mathrm{sec}^{-1}\right)$. M-modified PNA-peptide conjugates were not cytotoxic and were efficiently delivered in the cytosol of HEK293 cells at $10 \mu$ M. Surprisingly, M-modified PNAs without peptide conjugation were also taken up by HEK293 cells, which, to the best of our knowledge, is the first example of heterocyclic base modification that enhances the cellular uptake of PNA. Our results suggest that M-modified PNA-peptide conjugates are promising probes for sequence-selective recognition of double-stranded RNA in live cells and other biological systems.
\end{abstract}

Keywords: cellular uptake of PNA; modified nucleobases; molecular recognition of RNA; peptide nucleic acid; triple helix

\section{INTRODUCTION}

A growing list of novel biological functions of RNA including gene regulation, catalysis, immunomodulation, and DNA cleavage and editing makes RNA an attractive target for molecular recognition (Bartel 2004, 2009; Ling et al. 2013). The majority of functional RNAs fold in well-organized doublestranded structures. Most naturally occurring noncoding RNAs are either completely double-helical with A-form conformations or globular with short double-helical domains connected by single-stranded regions; prominent examples are microRNA precursors (Lee et al. 2002; Bonnet et al. 2004; Quarles et al. 2013), transfer RNAs, ribosomal RNAs (Chow and Bogdan 1997; Lescoute and Westhof 2006; Cruz and Westhof 2009), and long noncoding RNAs (Mercer and Mattick 2013). Sequence-specific recognition of such double-stranded RNAs (dsRNAs) would be an attractive

Corresponding authors: dhnedzk1@binghamton.edu, erozners@ binghamton.edu

Article is online at http://www.rnajournal.org/cgi/doi/10.1261/rna.058362. 116. tool with broad applications in biology, biotechnology, and medicinal chemistry.

One of the most straightforward ways of sequence-selective recognition of dsRNA would be a major groove triple helix formation (Devi et al. 2015). However, due to electrostatic repulsion of negatively charged oligonucleotides, traditional triple helices are significantly less stable and slow to form compared with duplexes. Recently, we discovered that peptide nucleic acids (PNAs) form an exceptionally stable and sequence-selective triple helix with dsRNA (Li et al. 2010; Zengeya et al. 2012; Annoni et al. 2016; Endoh et al. 2016). RNA triplexes were scarcely addressed in the literature prior to our studies (Roberts and Crothers 1992; Escude et al. 1993; Han and Dervan 1993; Zhou et al. 2013) and triple helical binding of PNA to double-stranded RNA was virtually unknown. The key modification of triplex-forming PNA was

(C) 2016 Hnedzko et al. This article is distributed exclusively by the RNA Society for the first 12 months after the full-issue publication date (see http://rnajournal.cshlp.org/site/misc/terms.xhtml). After 12 months, it is available under a Creative Commons License (Attribution-NonCommercial 4.0 International), as described at http://creativecommons.org/licenses/by$\mathrm{nc} / 4.0 /$. 
replacement of cytosine with a more basic $\left(\mathrm{p} K_{\mathrm{a}} \sim 6.7\right) 2$-aminopyridine nucleobase ( $\mathrm{M}$ modification, for structure, see Fig. 1) that enabled strong (low nanomolar range) and selective RNA recognition at physiologically relevant conditions (Zengeya et al. 2012). Before our work, 2-aminopyridine C-nucleoside had been used as a protonated cytidine equivalent to improve DNA triple-helix formation at high $\mathrm{pH}$ (Bates et al. 1996; Hildbrand and Leumann 1996; Hildbrand et al. 1997), but was never explored as a PNA nucleobase. Conjugation of M-modified PNA with four lysine residues showed promising increase in uptake by HEK293 cells (Muse et al. 2013). In these preliminary studies we also discovered that M-modified PNAs had unique selectivity for binding RNA, as a PNA-dsRNA triplex was significantly more stable than a PNA-dsDNA triplex of the same sequence (Zengeya et al. 2012; Muse et al. 2013). Herein, we report the surprising result that $\mathrm{M}$-modification also significantly enhances PNA uptake in HEK293 cells. Thus, M is a unique nucleobase modification that serves two functions: (i) enables sequence-selective recognition of dsRNA at physiologically relevant $\mathrm{pH}$ of 7.4, and (ii) enhances cellular delivery of PNA. Furthermore, low cytotoxicity of M-modified PNA makes it a good candidate for practical applications in biological systems.

Applications of unmodified PNAs are limited by their poor cellular uptake and endosomal entrapment. Several approaches have been undertaken to address this issue, including microinjection, electroporation, DNA-mediated transduction, conjugation to cell penetrating peptides (CPPs), endosomolytic treatment, and cationic backbone modifications (Koppelhus and Nielsen 2003; Zhou et al. 2003; Shiraishi and Nielsen 2006; Sahu et al. 2009; Rozners 2013). These various strategies have yielded some success, but often at the expense of increased synthetic complexity, lower binding affinity or sequence-selectivity, acute immune responses, and toxicity to cells. Recently, the groups of Corey (Hu and Corey 2007; Hu et al. 2009) and Gait (Turner et al. 2005; Fabani and Gait 2008) showed that conjugation of PNA with short oligolysine peptides enabled efficient delivery in various cancer cell lines. Using short oligolysine instead of longer CPP significantly reduced the synthetic complexity required for PNA use in biological systems (Fabani et al. 2010; Wancewicz et al. 2011).

In recent short communications (Zengeya et al. 2012; Muse et al. 2013) we reported preliminary observations that 2-aminopyridine-modified PNAs and their conjugates with lysine peptides formed stable and sequence-selective triple helices with dsRNA and demonstrated promising cellular uptake. Herein, we report detailed studies on RNA binding affinity, sequence selectivity and kinetics, and cellular uptake, localization, and cytotoxicity of an extended series of M- and peptide-modified PNAs (Fig. 1B,D). All PNA sequences showed high affinity $\left(K_{\mathrm{a}}\right.$ up to $\left.10^{8} \mathrm{M}^{-1}\right)$, good sequence selectivity, and relatively fast kinetics of triple helical binding to dsRNA at physiologically relevant conditions. Addition of cationic peptides increased binding affinity without compromising sequence selectivity. Cellular uptake of PNA was significantly enhanced by replacing all cytosines with $M$ nucleobases. An M-modified PNA 9mer was able to enter HEK293 cells at low micromolar concentrations even without CPP attachment. The uptake increased as the number of $\mathrm{M}$ nucleobases increased in a PNA 12mer, which, to the best of our knowledge, is the first example of a heterocyclic base modification that enhances the cellular uptake. Conjugation of M-modified PNAs with additional three lysine or arginine residues further improved their cellular uptake. The XTT proliferation assay showed that the PNAs were not cytotoxic up to the $10 \mu \mathrm{M}$ concentration. These results

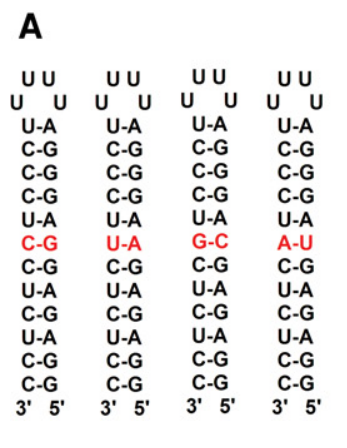

HRP 1 HRP 2 HRP 3 HRP 4
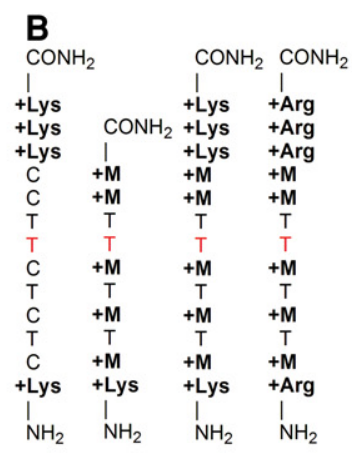

PNA 1 PNA 2

PNA 3

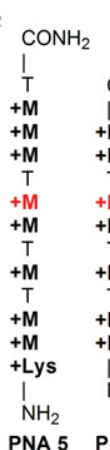

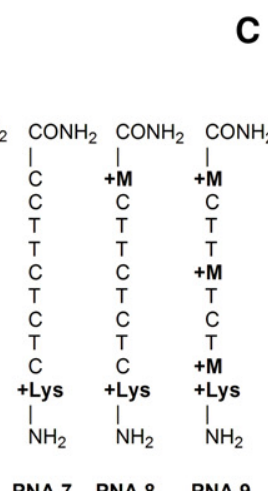

PNA 7 PNA 8 PNA 9

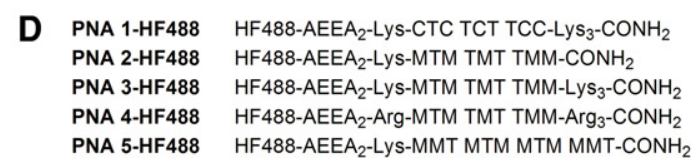

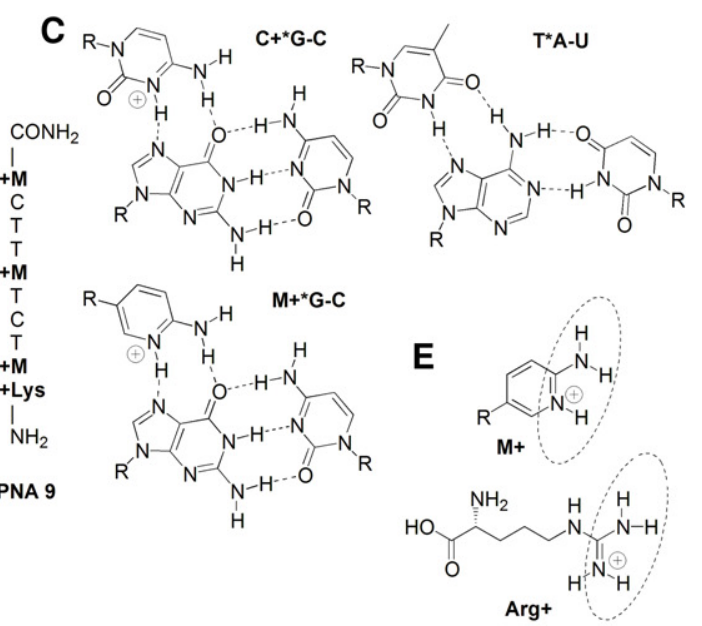

FIGURE 1. Sequences of RNA hairpins $(A)$ and triplex-forming PNAs $(B, D)$, structures of native and M-modified Hoogsteen base triplets $(C)$, and comparison of hydrogen binding schemes of protonated $\mathrm{M}$ and arginine $(E)$. 
are very encouraging and suggest that M-modified PNAs may become a novel tool in applications requiring molecular recognition of dsRNA in live cells.

\section{RESULTS}

\section{RNA binding affinity and selectivity of $M$ - and peptide-modified PNAs}

We started the biophysical characterization of M- and peptide-modified PNAs with evaluation of their RNA binding affinity and sequence selectivity. We synthesized a series of sequences, PNA 1 through PNA 6 (Fig. 1B, for MS data see Supplemental Table S2) and studied their binding to four model hairpins HRP 1-HRP 4 (Fig. 1A) using isothermal titration calorimetry (ITC). As we have previously observed with similar but shorter PNA sequences (Muse et al. 2013), PNA 1 having only additional Lys modifications had very weak affinity for the cognate RNA hairpin at physiological $\mathrm{pH}$ and salt concentration (Table 1; for complete ITC data, see Supplemental Table S1). In contrast, PNA 2 with five $\mathrm{M}$ bases replacing cytosines showed strong binding affinity and good sequence selectivity. Addition of three lysines almost doubled the binding affinity of PNA 3 without compromising sequence selectivity. Conjugation with four arginines showed similar effect in PNA 4. Overall, the data in Table 1 show that M-modified PNAs with and without short cationic peptides displayed strong and sequence-selective triple helix formation with dsRNA.

Comparison of 9mers PNA 2 (five Ms) and PNA 6 (six Ms) suggested that the binding affinity increased with increasing number of $\mathrm{M}$ modifications. To further explore the role of $\mathrm{M}$ modification and $\mathrm{pH}$ in triple-helical recognition of dsRNA, we prepared a series of PNAs with a variable number of M replacing cytosines (PNA 7-PNA 9, Fig. 1B) and studied their binding to the matched HRP 2 at different $\mathrm{pH}$ values. The results in Table 2 showed that binding affinity increased

TABLE 1. Binding affinity and sequence selectivity of M-modified PNAs to RNA (HRP 1-HRP 4) and DNA (dsDNA 1-dsDNA 2) hairpins (see also Supplemental Table S1) ${ }^{\mathrm{a}}$

\begin{tabular}{lcrcccc}
\hline & HRP & HRP & HRP & HRP & dsDNA & dsDNA \\
PNA (design) & \multicolumn{1}{c}{1} & \multicolumn{1}{c}{$\begin{array}{c}\text { H } \\
\text { PN }\end{array}$} & \multicolumn{1}{c}{4} & 1 & 2 \\
\hline PNA 1 (K-5Cs-K3) & NB $^{\mathrm{b}}$ & 0.4 & NB $^{\mathrm{b}}$ & $\mathrm{NB}^{\mathrm{b}}$ & - & - \\
PNA 2 (K-5Ms) & 11 & $\mathbf{9 4}$ & 3 & 3 & - & 0.5 \\
PNA 3 (K-5Ms-K3) & 12 & $\mathbf{1 7 0}$ & 8 & 12 & - & 5 \\
PNA 4 (R-5Ms-R3) & 20 & $\mathbf{1 6 0}$ & 9 & 28 & - & 5 \\
PNA 5 (K-8Ms) & $\mathbf{1 2 0}$ & 16 & 7 & 5 & 11 & - \\
PNA 6 (K-6Ms) & $\mathbf{1 1 0}$ & 9 & 6 & 3 & 3 & -
\end{tabular}

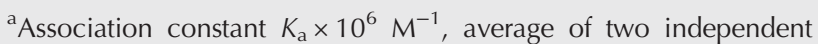
experiments measured using a MicroCal iTC200 instrument in 2 $\mathrm{mM} \mathrm{MgCl} 2,90 \mathrm{mM} \mathrm{KCl}, 10 \mathrm{mM} \mathrm{NaCl}, 50 \mathrm{mM}$ potassium phosphate buffer $(\mathrm{pH} 7.4)$ at $25^{\circ} \mathrm{C}$. The bold entries represent the affinities of the matched triple helices.

$\mathrm{b}(\mathrm{NB})$ No binding; $K_{\mathrm{a}}<10^{3} \mathrm{M}^{-1}$.
TABLE 2. Binding affinity of 9 mer PNAs to the matched HRP 2 depends on the number of $\mathrm{M}$ and $\mathrm{pH}$ (see also Supplemental Table S1) $)^{\mathrm{a}}$

\begin{tabular}{lcccc}
\hline & $\begin{array}{c}\text { PNA 7 } \\
\text { (no M) }\end{array}$ & $\begin{array}{c}\text { PNA 8 } \\
\text { (one M) }\end{array}$ & $\begin{array}{c}\text { PNA 9 } \\
\text { (three Ms) }\end{array}$ & $\begin{array}{c}\text { PNA 2 } \\
\text { (five Ms) }\end{array}$ \\
\hline $\mathrm{pH} \mathrm{6.5}$ & 0.7 & 3 & 72 & 390 \\
$\mathrm{pH} \mathrm{7.4}$ & NB $^{\mathrm{b}}$ & 2 & 5 & 94 \\
$\mathrm{pH} \mathrm{8.0}$ & NB $^{\mathrm{b}}$ & $\mathrm{NB}^{\mathrm{b}}$ & $\mathrm{NB}^{\mathrm{b}}$ & 7 \\
\hline
\end{tabular}

${ }^{a}$ Association constant $K_{\mathrm{a}} \times 10^{6} \mathrm{M}^{-1}$, average of two independent experiments measured using a MicroCal iTC200 instrument in 2 $\mathrm{mM} \mathrm{MgCl} 2,90 \mathrm{mM} \mathrm{KCl}, 10 \mathrm{mM} \mathrm{NaCl}, 50 \mathrm{mM}$ potassium phosphate buffer at $25^{\circ} \mathrm{C}$.

(NB) No binding; $K_{\mathrm{a}}<10^{3} \mathrm{M}^{-1}$.

with increasing the number of $\mathrm{M}$ modifications and lowering the $\mathrm{pH}$. PNA 7 with no $\mathrm{M}$ modifications had low, if any, affinity for HRP 2 at all $\mathrm{pH}$ values tested. Introducing one $\mathrm{M}$ modification in PNA 8 resulted in a detectable binding at $\mathrm{pH} 6.5$ and 7.4, which was strongly enhanced in PNA 9 having three Ms. Consistent with the estimated $\mathrm{p} K_{\mathrm{a}}$ of 2 -aminopyridine being around 6.7, decrease of $\mathrm{pH}$ from 7.4 to 6.5 resulted in a fourfold increase of binding affinity for PNA 2 that had all cytosines replaced by $\mathrm{M}$ nucleobases. Overall, the data in Tables 1 and 2 clearly demonstrated that $\mathrm{M}$ was the key modification enabling strong and selective recognition of dsRNA at physiologically relevant $\mathrm{pH}$ and salt concentration. As will be illustrated later, we also discovered that $\mathrm{M}$ has another important and unexpected ability to enhance the cellular uptake of PNA.

To compare the relatively little studied PNA-dsRNA triplex with the better known PNA-dsDNA triplex (Hansen et al. 2009), we studied binding of PNA 2-PNA 6 to their matched DNA hairpins, dsDNA 1 and dsDNA 2 (Table 1). Consistent with our previous preliminary observations (Zengeya et al. 2012; Muse et al. 2013) PNA-dsRNA triplexes were significantly more stable than the corresponding PNAdsDNA triplexes. The difference was most noticeable for the shorter 9mers, where PNA 2 had more than two orders of magnitude higher affinity for HRP 2 than for dsDNA 2. The difference somewhat decreased with addition of peptide residues and lengthening of PNA; nevertheless, the affinity of 12 mer PNA 5 was $\sim 11$ times higher for HRP 1 than for dsDNA 1. To compare the PNA-dsRNA triplex to the well-established PNA-DNA duplex, we studied binding of PNA 1 to the complementary single-stranded DNA 3, 5'-d (AGGGAAGAGAGG) under physiological pH and salt conditions. Interestingly, the stability of duplex formed by PNA 1 and ssDNA 3 (Supplemental Table S1, $K_{\mathrm{a}}=1.5 \times$ $10^{7} \mathrm{M}^{-1}$ ) was about an order of magnitude lower than the stability of triplex formed by PNA 3 and HRP 2 (Table 1, $\left.K_{\mathrm{a}}=1.7 \times 10^{8} \mathrm{M}^{-1}\right)$. The ITC results were further confirmed by UV thermal melting (Fig. 2). The duplex formed by PNA 1 and ssDNA 3 melted in one single transition at $\sim 47^{\circ} \mathrm{C}$. The melting curves of triplexes showed two transitions. The lower 


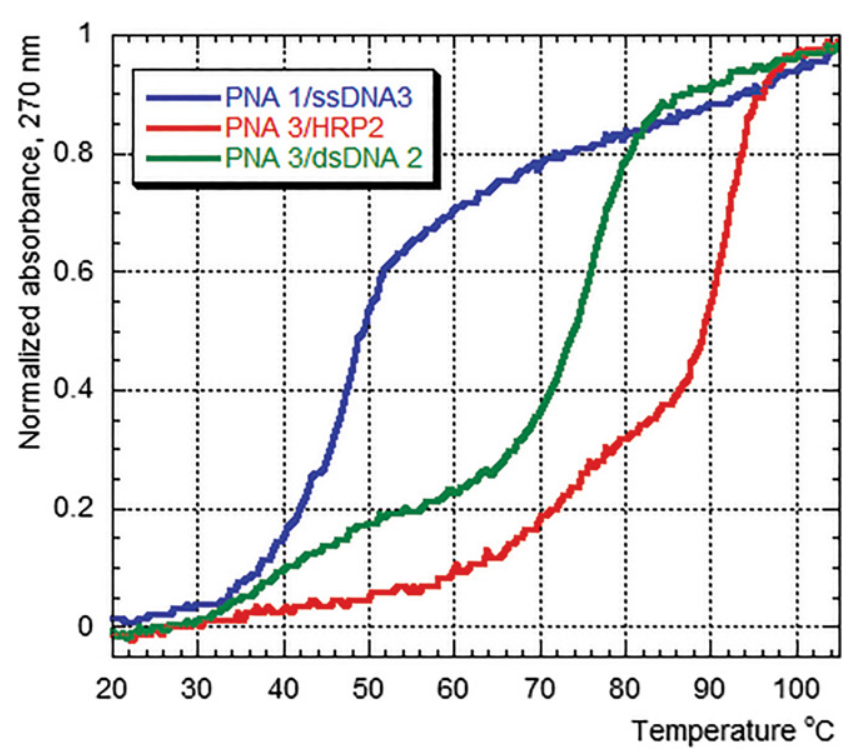

FIGURE 2. UV-melting curves of the duplex formed by PNA 1 and ssDNA 3 (blue), triplex formed by PNA 3 and dsDNA 2 (green), and triplex formed by PNA 3 and HRP 2 (red). Conditions: $2 \mathrm{mM} \mathrm{MgCl}$, $90 \mathrm{mM} \mathrm{KCl}, 10 \mathrm{mM} \mathrm{NaCl}, 50 \mathrm{mM}$ potassium phosphate buffer $(\mathrm{pH}$ 7.4). The final concentration of each complex was $2 \mu \mathrm{M}$. Data were collected every $0.5^{\circ} \mathrm{C}$ during a heating ramp of $0.5^{\circ} \mathrm{C} / \mathrm{min}$.

temperature transitions were assigned to the dissociation of PNA third strand from hairpins, while the higher temperature transitions were due to hairpin melting. Consistent with the ITC results, the dissociation of PNA 3 from dsDNA 2 occurred at $\sim 39^{\circ} \mathrm{C}$, while the dissociation of PNA 3 from HRP 2 took place at a significantly higher temperature of $\sim 70^{\circ} \mathrm{C}$. Taken together, our results illustrate that PNA has a unique affinity for dsRNA that makes PNA-RNA triplexes significantly more stable than PNA-DNA triplexes or duplexes.

\section{Kinetics of triplex formation of $\mathrm{M}$ - and peptide-modified PNAs}

The kinetics of triplex formation was studied using PNA 3 labeled at the amino terminus with HiLyte Fluor 488 dye (PNA 3-HF488, Fig. 1D) that was prepared following our recently developed methodology (Hnedzko et al. 2016). The binding kinetics were studied using the stopped-flow method under pseudo-first order conditions where PNA 3HF488 was mixed with 10 equivalents of HRP 2 labeled at the $5^{\prime}$-end with Black Hole Quencher 1 (HRP 2-BHQ1) in phosphate buffer $(\mathrm{pH} 7.4)$ at $25^{\circ} \mathrm{C}$. The binding of PNA 3-HF488 to HRP 2-BHQ1 resulted in a time-dependent decrease in HiLyte Fluor 488 fluorescence (Fig. 3, black trace). Consistent with our previous results (Hnedzko et al. 2016), photobleaching of PNA 3-HF488 under these conditions was relatively slow (Fig. 3, red trace). Fitting of the fluorescence decay curve with a single exponential decay equation (for details, see Materials and Methods) gave the observed pseudo-first order rate constant $k_{\mathrm{obs}}=0.015 \pm 0.001 \mathrm{sec}^{-1}$. Using the approach described by Xodo (1995) for calculation of the second order association rate constant gave $k_{\mathrm{on}}=2.9 \times$ $10^{4} \pm 0.2 \mathrm{M}^{-1} \mathrm{sec}^{-1}$. This result confirmed that binding of the cationic PNA-peptide conjugate to dsRNA was faster than $k_{\text {on }} \sim 10^{3} \mathrm{M}^{-1} \mathrm{sec}^{-1}$, which has been reported for triplex-forming oligonucleotides (Xodo 1995; Alberti et al. 2002) and consistent with our hypothesis that electrostatic repulsion is the major problem for formation of the traditional triple helices.

\section{Cellular uptake and localization of $\mathrm{M}$ - and peptide-modified PNAs}

To investigate the role of $\mathrm{M}$ modification in cellular internalization of PNA, we used our recently developed methodology (Hnedzko et al. 2016) to prepare a set of fluorescently labeled PNA sequences shown in Figure 1D. PNA 1 was conjugated to four L-lysine residues, one lysine at the $\mathrm{N}$ terminus and three lysine residues at the $\mathrm{C}$ terminus, to evaluate PNA uptake due to lysine residues in the absence of $\mathrm{M}$ modifications. Fabani and Gait (2008) showed that $(\mathrm{K})_{3}$ conjugation at the carboxylic terminus was responsible for uptake of the K-PNA-K3 construct as substitution of lysine with neutral 3 -glutamic acid residues canceled the biological activity.

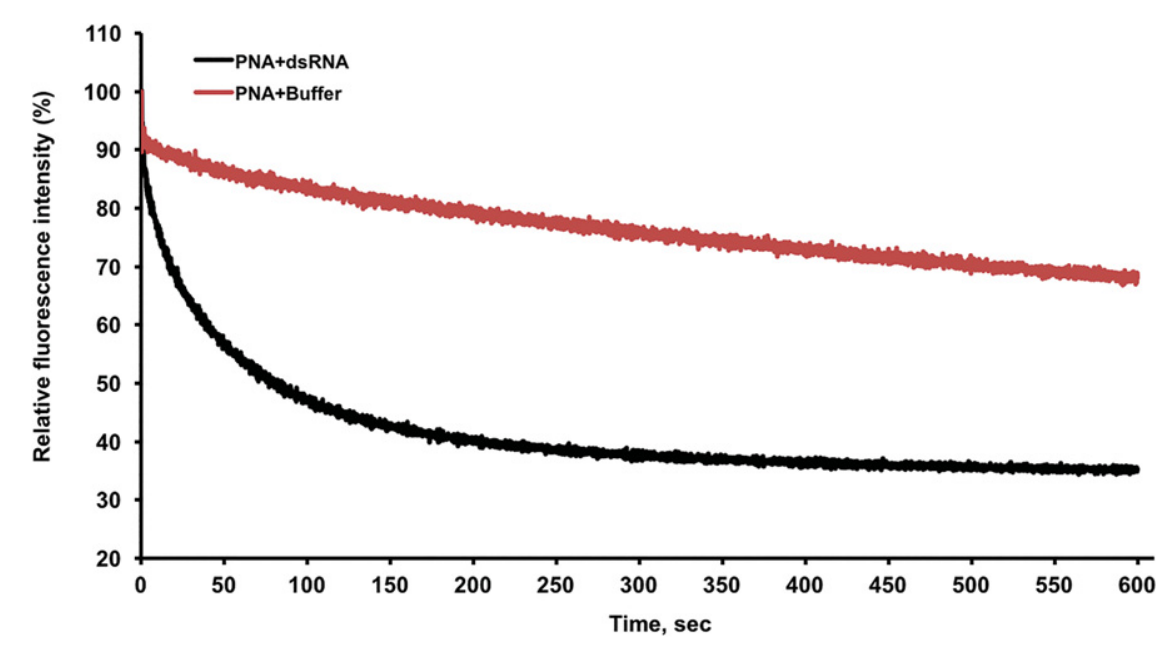

FIGURE 3. Stopped-flow kinetics of PNA 3-HF488 binding to HRP 2-BHQ1 in physiological phosphate buffer: $2 \mathrm{mM} \mathrm{MgCl}_{2}, 90 \mathrm{mM} \mathrm{KCl}, 10 \mathrm{mM} \mathrm{NaCl}, 50 \mathrm{mM}$ potassium phosphate ( $\mathrm{pH}$ 7.4) at $25^{\circ} \mathrm{C}$. The black kinetic trace shows the time-dependent decrease of HiLyte Fluor 488 fluorescence (excitation at $501 \mathrm{~nm}$ and emission at $528 \mathrm{~nm}$ ) after mixing $0.1 \mu \mathrm{M}$ HF488PNA 3 and $1.0 \mu \mathrm{M}$ BHQ1-HRP 2 (starting concentrations). The kinetic trace shown is an average of five measurements. The red trace is a blank experiment where PNA 3-HF488 was mixed with buffer to show the photobleaching of HF-488 under the conditions used for kinetic experiments. 
PNA 2 had all cytosines replaced with $M$ (total of five $M$ modifications) to examine the effect of $\mathrm{M}$ on cellular uptake of PNA. PNA 3 combined the features of both PNA 1 and PNA 2 to determine the effect of $(K)_{3}$ addition to the Mmodified sequence. PNA 4 was modified with four L-arginine residues to test another commonly used CPP. Finally, PNA 5 had eight $M$ modifications to examine the effect of three additional Ms on cellular uptake of PNA.

The cellular uptake of M-modified PNA sequences was first studied using flow cytometry (Fig. 4). HEK293 cells were treated with $1 \mu \mathrm{M}$ of HF488-labeled PNA constructs in OptiMEM (without FBS) in the absence of any transfection agent at $37^{\circ} \mathrm{C}, 10 \% \mathrm{CO}_{2}$. Cells were incubated for different time periods (30 min, 1, 4, 12, and $24 \mathrm{~h}$ ), trypsin-treated to detach the cells and remove peptides adsorbed to the outer plasma membrane, and analyzed using a FACSCalibur flow cytometer. All PNA sequences studied showed time-dependent internalization (Fig. 4). Doubly modified PNA 3 and PNA 4, and PNA 5 having eight $M$ modifications showed significant cellular uptake $(>60 \%)$ within $12 \mathrm{~h}$. In contrast, PNA 1 having only Lys modifications and PNA 2 having only five $M$ modifications showed $<50 \%$ uptake even after $24 \mathrm{~h}$ of incubation. Combination of Lys and M modifications in PNA 3 increased the internalization to $60 \%$ after $12 \mathrm{~h}$ and $70 \%$ after $24 \mathrm{~h}$, which suggested that both modifications contribute to the cellular uptake of PNA molecules.

Surprisingly, PNA 5 with eight $M$ modifications and no additional lysine or arginine attachments showed cellular uptake similar to PNA 3 and 4. Thus, addition of three more M modifications enhanced PNA cellular uptake to the level sim-

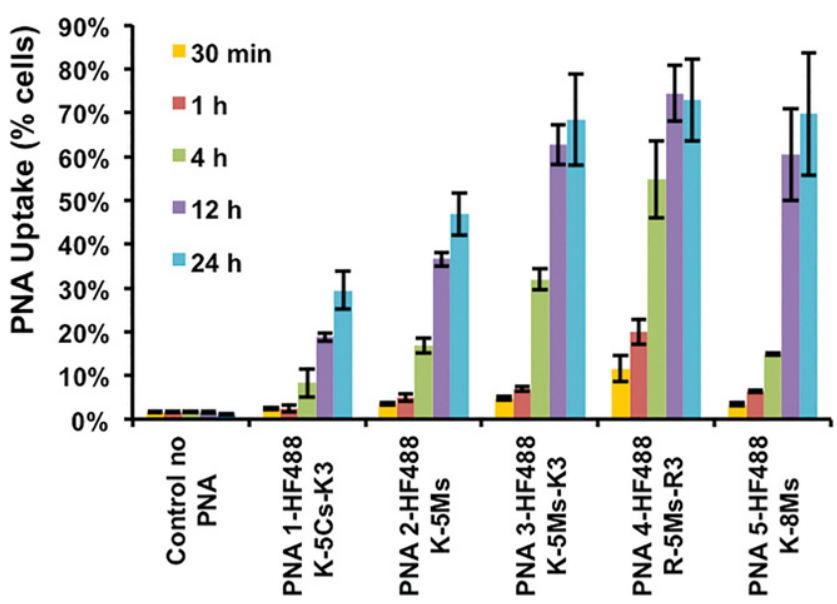

FIGURE 4. Flow cytometric analysis of HEK293 cells treated with HiLyte Fluor 488-labeled PNAs at $1 \mu \mathrm{M}$ concentration in OptiMEM for $30 \mathrm{~min}$ (yellow), $1 \mathrm{~h}$ (dark red), $4 \mathrm{~h}$ (olive green), $12 \mathrm{~h}$ (purple), and $24 \mathrm{~h}$ (light blue). Cells (10,000 events for each sample) were analyzed using a FACSCalibur flow cytometer and the data were analyzed using the CellQuest Pro software. For each experiment, a control of cells that were not incubated with PNA was analyzed and used to designate negative events (no PNA). The data from three independent experiments are presented as the mean percentage of cells that are PNA positive \pm SE. ilar to that of PNA-CPP conjugates. However, internalization of peptide-conjugated PNA 3 and 4 occurred faster than internalization of PNA 5. After $4 \mathrm{~h}$ of incubation, PNA 5 showed only $15 \%$ uptake compared to $30 \%$ for PNA 3 and $55 \%$ for PNA 4, which may be due to the difference in size of these PNA molecules or may indicate different mechanisms of cellular uptake. The arginine-modified PNA 4 showed fast and efficient cellular uptake that was superior to all other PNAs studied.

To get more insight into the mechanism of uptake and intracellular localization of M-modified PNA constructs, we used live-cell confocal microscopy. HEK293 cells were incubated with $1 \mu \mathrm{M}$ concentration of HF488-labeled PNA constructs in OptiMEM (without FBS) in the absence of any transfection agent for $24 \mathrm{~h}$ at $37^{\circ} \mathrm{C}, 10 \% \mathrm{CO}_{2}$. After the incubation period, cells were washed with OptiMEM before staining with LysoTracker Deep Red to track acidic organelles, and with 4',6-diamidino-2-phenylindole (DAPI) to distinguish nuclei. The images (Fig. 5) were taken using an inverted Axiovert Zeiss Laser Scanning Microscope 510 with a $63 \times$ objective.

Live-cell microscopy confirmed PNA cellular uptake. All PNAs studied (green fluorescence) appeared as dot-like structures within the cytoplasm. We could not observe localization of M-modified PNAs to the cell nuclei. PNA 3, 4, and 5 showed significantly better cell internalization compared to PNA 1 and 2, which was in a good agreement with the flow cytometry results. The majority of punctated green fluorescence was colocalized (yellow staining) with LysoTracker Deep Red, suggesting that cellular delivery of M-modified PNAs occurred mainly through endocytotic pathways and that a major fraction of internalized PNAs were retained in the endosome-lysosome compartments. However, the merged images of PNA 3 and 4 in Figure 3 also showed green fluorescence that was not colocalized with acidic compartments of the cell, suggesting that at least some PNA was released in cytoplasm.

Sequestration of PNAs within endosomal or other membrane-bound cytosolic compartments might be a limiting factor for targeting dsRNA in live cells. We therefore decided to use a known lysosomotropic reagent chloroquine to promote the disruption of endosomal-lysosomal compartments to release PNA molecules. Chloroquine has been used in several previous studies to increase biological activity of CPPPNA conjugates (Turner et al. 2005; Abes et al. 2006). HEK293 cells were incubated with $1 \mu \mathrm{M}$ concentration of HF488-labeled PNA constructs in OptiMEM in the presence of $100 \mu \mathrm{M}$ chloroquine for $24 \mathrm{~h}$ at $37^{\circ} \mathrm{C}, 10 \% \mathrm{CO}_{2}$. Interestingly, the results (Fig. 6) showed that coadministration of the lysosomotropic reagent chloroquine had little, if any, effect on cellular distribution of PNAs. The fluorescence remained punctate, similar to that in the absence of chloroquine.

Concentration of PNA is an important factor that affects the mechanism of CPP-conjugated PNA entry into cells 


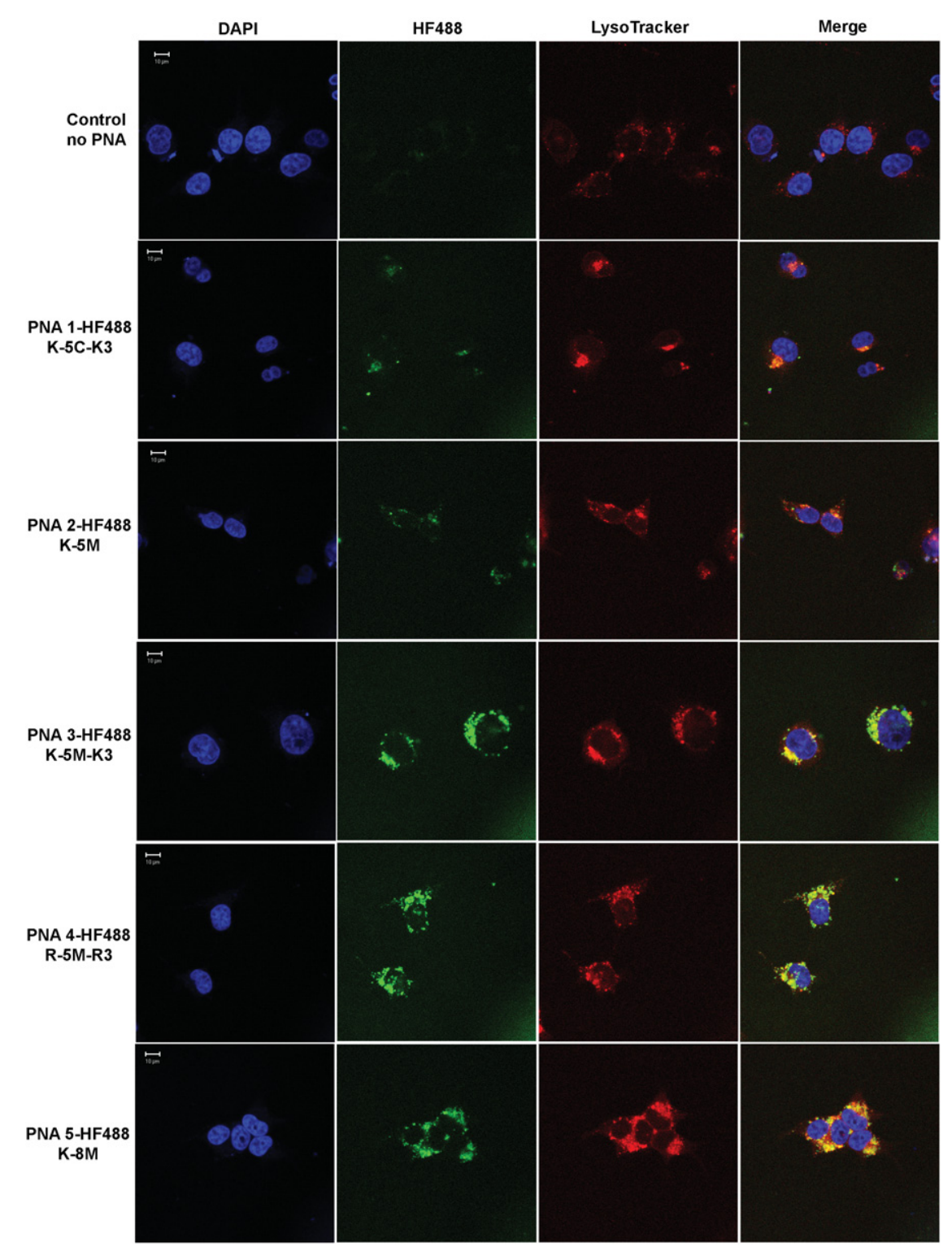

FIGURE 5. Live cell confocal microscopy of HEK293 cells treated with $1 \mu \mathrm{M}$ HiLyte Fluor 488labeled PNAs (green) in OptiMEM after $24 \mathrm{~h}$ of incubation at $37^{\circ} \mathrm{C}, 10 \% \mathrm{CO}_{2}$. After incubation, cells were washed with OptiMEM before addition of LysoTracker Deep Red to stain acidic organelles (red) and DAPI to stain the nuclear DNA (blue). Uptake of HF488-labeled PNAs showed green fluorescence measured at $488 \mathrm{~nm}$. All images were taken with the same confocal microscope settings.

(Fuchs and Raines 2004; Abes et al. 2006; Madani et al. 2011). We therefore asked if increase of concentration could change cellular localization of studied M-modified PNA conjugates. When HEK293 cells were incubated with $10 \mu \mathrm{M}$ PNA concentration in OptiMEM for $24 \mathrm{~h}$ at $37^{\circ} \mathrm{C}, 10 \% \mathrm{CO}_{2}$, cytoplasmic delivery of PNA was strongly enhanced (Fig. 7). More importantly, in addition to punctate structures in the cytosol, M-modified PNA conjugates showed significant uniform fluorescence in the cytosol (Fig. 7, red circles). Hence, the problem of endosomal compartmentalization could be overcome by increasing the concentration of M-modified PNAs.
An important limiting factor of live cell application of cationic PNA at high concentrations may be its cytotoxicity. We examined the viability of HEK293 cells using a colorimetric XTT proliferation assay. The tetrazolium salt XTT is reduced to colored formazan by a complex cellular mechanism that is inactivated shortly after cell death. The amount of formazan dye formed is directly proportional to the number of metabolically active cells in the culture. The cells were incubated with different concentrations of M-modified PNA sequences in OptiMEM (without FBS) for $24 \mathrm{~h}$ at $37^{\circ} \mathrm{C}, 10 \% \mathrm{CO}_{2}$. No significant toxicity was observed for M-modified PNA sequences up to $10 \mu \mathrm{M}$ (Fig. 8). Statistical analysis showed that the apparent differences between PNAs at $10 \mu \mathrm{M}$ and the respective controls in Figure 8 were not significant. However, at higher concentrations $(20 \mu \mathrm{M})$, toxicity of the polypeptide-modified PNA sequences increased. The arginine-modified PNA 4 had the strongest cytotoxicity.

\section{DISCUSSION}

One of the surprising results of the Human Genome Project was that only a few percent of our DNA encodes for functional proteins, while most of our DNA is transcribed into functional RNAs (Dunham et al. 2012). To study the biological function of noncoding RNAs, we need new chemical probes capable of sequence-selective recognition and functional interference with complex structured RNA molecules. Our recent work suggested that nucleobase-modified and lysine-conjugated PNAs are promising tools for molecular recognition of dsRNA via sequence-selective triple helix formation (Li et al. 2010; Zengeya et al. 2012; Muse et al. 2013). Herein, we extended these preliminary results in a detailed study of dsRNA recognition and cellular uptake of triplex-forming PNAs. Our results showed that all M-modified PNAs and their conjugates with lysine and arginine tripeptides formed very strong $\left(K_{\mathrm{a}}=9.4-17 \times 10^{7} \mathrm{M}^{-1}\right)$ and sequence-selective triple helices with dsRNA at physiologically relevant conditions. Addition of cationic peptides increased binding affinity without compromising sequence selectivity. Compared to triple helices formed by natural oligonucleotides $\left(k_{\mathrm{on}} \sim 10^{3} \mathrm{M}^{-1} \sec ^{-1}\right)$, formation of the PNA- 


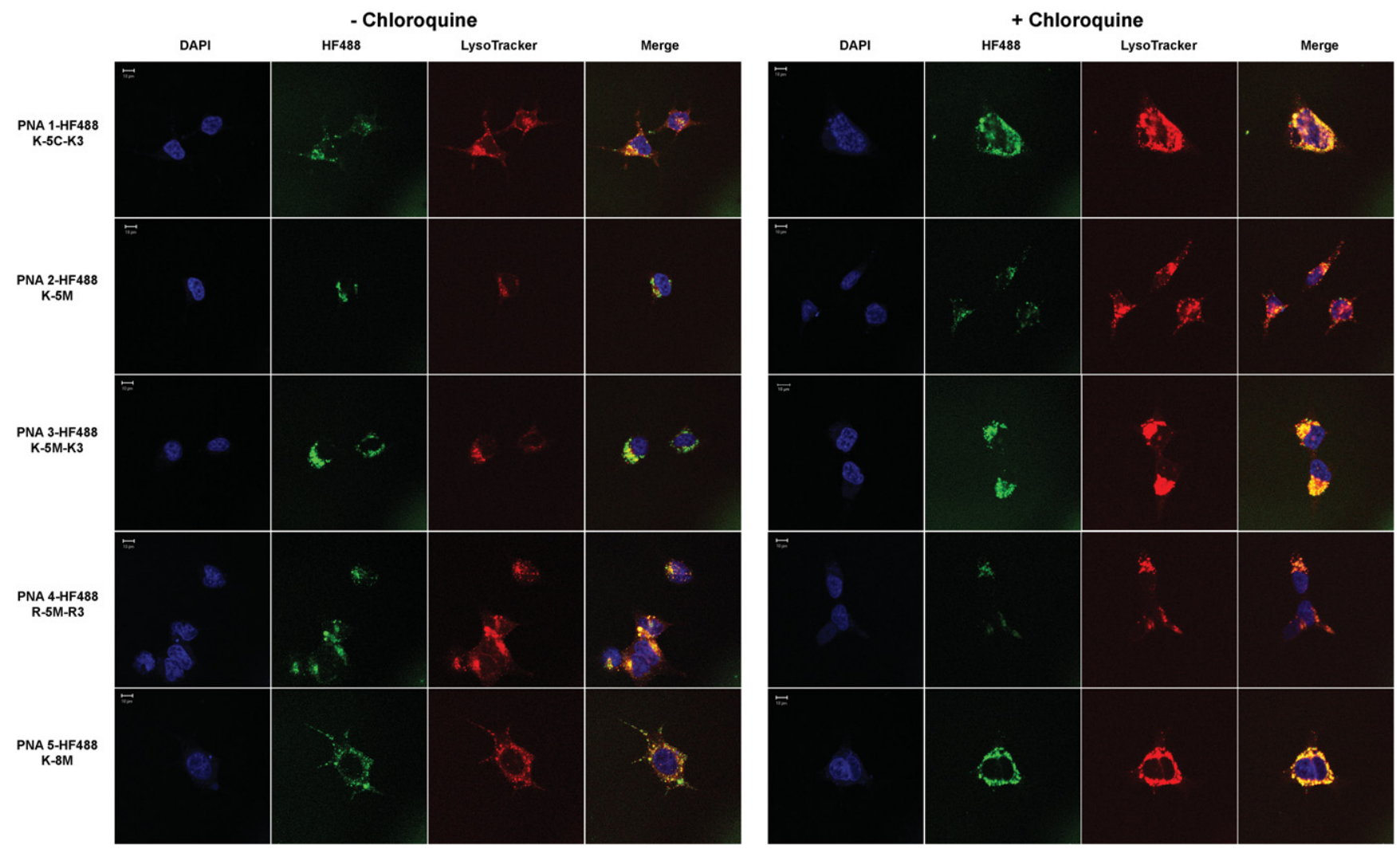

FIGURE 6. Effect of chloroquine addition on PNA cytoplasmic distribution. Live cell confocal microscopy of HEK293 cells treated with (left) $1 \mu \mathrm{M}$ PNA-HF488 in OptiMEM or (right) $1 \mu \mathrm{M}$ PNA-HF488/100 $\mu \mathrm{M}$ chloroquine in OptiMEM after $24 \mathrm{~h}$ of incubation at $37^{\circ} \mathrm{C}, 10 \% \mathrm{CO}_{2}$. After incubation, cells were washed with OptiMEM before addition of LysoTracker Deep Red to stain acidic organelles (red) and DAPI to stain the nuclear DNA (blue). Uptake of HF488-labeled PNAs showed green fluorescence measured at $488 \mathrm{~nm}$.

dsRNA triplex was more than an order of magnitude faster $\left(k_{\text {on }}=2.9 \times 10^{4} \mathrm{M}^{-1}\right.$ $\left.\mathrm{sec}^{-1}\right)$. The fast and strong binding of cationic M-modified PNAs to dsRNA was fully consistent with our hypothesis that electrostatic repulsion is a major impeding factor for formation of natural triple helices.

Most interestingly, binding of PNAs to dsRNA was significantly stronger (10180 times, Table 1) than to the same sequence of dsDNA. The relatively low affinity of M-modified PNAs for matched dsDNA was not surprising and consistent with results by Nielsen and coworkers (Hansen et al. 2009) who studied PNAdsDNA triplexes where all cytosines were replaced by pseudoisocytosines (J nucleobases), a neutral mimic of protonated cytosine. In their hands, J-modified PNA 10mer did not form a triplex with dsDNA. However, a J-modified PNA 15 mer did bind to dsDNA with $K_{\mathrm{a}}=$ $0.67 \times 10^{7} \mathrm{M}^{-1}$, which was further

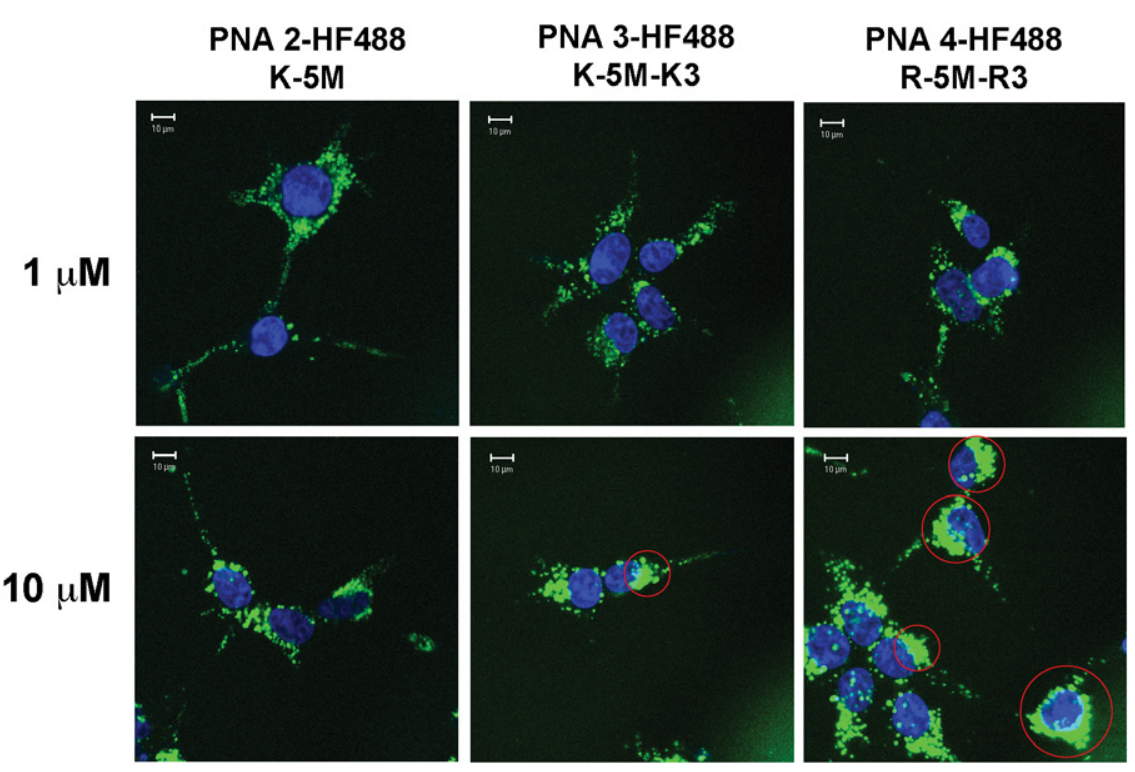

FIGURE 7. Concentration-dependent uptake of PNA sequences and lysosomal escape. Live cell confocal microscopy of HEK293 cells treated with (top) $1 \mu \mathrm{M}$ PNA-HF488 in OptiMEM or (bottom) $10 \mu \mathrm{M}$ PNA-HF488 in OptiMEM after $24 \mathrm{~h}$ of incubation at $37^{\circ} \mathrm{C}, 10 \% \mathrm{CO}_{2}$. After incubation, cells were washed with OptiMEM before addition of DAPI to stain the nuclear DNA (blue). Uptake of HF488-labeled PNAs showed green fluorescence measured at $488 \mathrm{~nm}$. All images were taken with the same confocal microscope settings. 


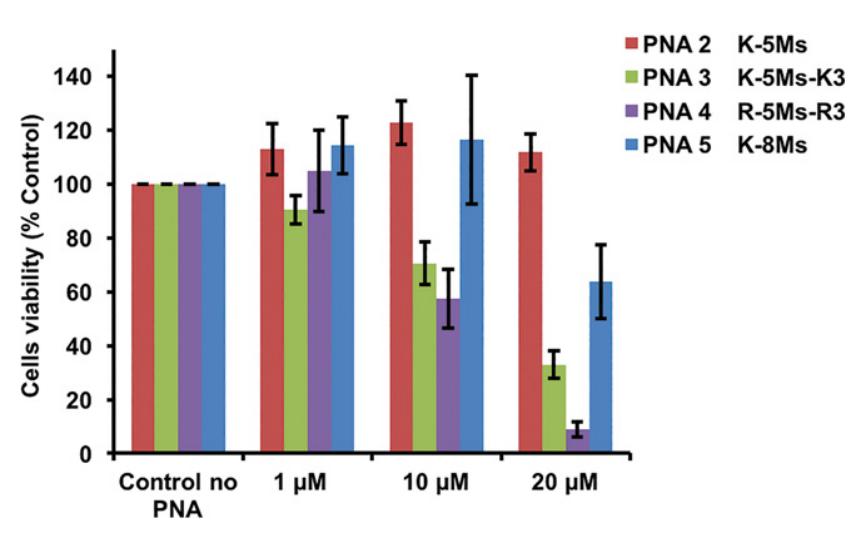

FIGURE 8. Dosage-dependent cytotoxicity profile of M-modified PNA conjugates on HEK293 cells after $24 \mathrm{~h}$ of incubation at $37^{\circ} \mathrm{C}, 10 \% \mathrm{CO}_{2}$, analyzed by the XTT assay. PNA 2 is represented by dark red bars, PNA 3 by olive green bars, PNA 4 by purple bars, and PNA 5 by light blue bars. The cell viability is presented as the percent of control (non-PNA-treated sample), a mean of three independent experiments \pm SE.

improved to $K_{\mathrm{a}}=14 \times 10^{7} \mathrm{M}^{-1}$ upon conjugation with three lysine residues (Hansen et al. 2009). Therefore, the surprising result was the unusually high affinity of our M-modified PNAs for dsRNA. Affinities of PNA 9mers for dsRNA in our study were equal and better than those of PNA 15mers for dsDNA in Nielsen's study. Thus, M-modified PNA has unique selectivity for binding dsRNA compared to dsDNA. While we do not have experimental data explaining such selectivity, it is conceivable that the deep and narrow major groove of an RNA helix may provide a better steric and electrostatic fit for the cationic PNA ligand than the wider major groove of a DNA helix.

Unmodified PNAs do not spontaneously enter the cell by passive diffusion through the cell membrane (Wittung et al. 1995). In contrast, M-modified PNAs and their peptide conjugates were efficiently taken up by HEK293 cells. At $1 \mu \mathrm{M}$ concentration, PNAs appeared as dot-like structures within the cytoplasm. When the concentration was increased to 10 $\mu \mathrm{M}$, cytoplasmic delivery of PNAs was strongly enhanced and M-modified PNA-peptide conjugates were able to escape endosomal entrapment. It is remarkable that $\mathrm{M}$-modified PNA sequences can be internalized by HEK293 cells at 1 $\mu \mathrm{M}$ concentration without the use of any transfecting agents or conjugation to cell penetrating peptides (CPPs). The uptake increased as the number of $\mathrm{M}$ nucleobases increased in the longer PNA 12mer. To the best of our knowledge, heterocyclic base modifications that enhance cellular uptake have not been described before. Addition of lysine or arginine tripeptides further improved cellular uptake of M-modified PNA sequences.

The mechanism for CPP-mediated internalization is complex and not completely understood; there is evidence for both endocytosis and energy-independent processes (Madani et al. 2011). Endocytosis is believed to be the most common uptake mechanism at low CPP concentrations.
Cationic PNAs with multiple lysine residues are taken up in HeLa cells through an endocytic mechanism and are sequestrated in endosomes (Abes et al. 2006). At low concentrations endocytosis prevails; however, at higher concentrations (5 or $10 \mu \mathrm{M})$ cellular uptake becomes faster and temperatureindependent, suggesting a switch to an energy-independent mechanism, possibly due to peptide-induced membrane permeabilization (Abes et al. 2006).

Arginine peptides (R9) were shown to be better carriers than oligomers of equal length composed of lysine, ornithine, or histidine (Mitchell et al. 2000). The guanidine head group of arginine is the critical structural component responsible for cellular uptake. This is supported by the failure of heptamers of citrulline, an isostere of arginine where the nitrogen of guanidine is replaced by oxygen, to enter cells. The ability of guanidine to form a very stable bidentate hydrogen bond with membrane anions, such as phosphate or sulfate, distinguishes arginine from lysine, and appears to cause the differences in cellular uptake of arginine and lysine peptides (Mitchell et al. 2000). The mechanistic studies reveal a four-step pathway for the entry of R9 into the cytoplasm of mammalian cells (Fuchs and Raines 2004). This pathway involves binding to the cell surface heparan sulfate, uptake by endocytosis, release upon heparan sulfate degradation, and leakage from endocytic vesicles when a high enough concentration of free R9 is reached (Fuchs and Raines 2004). Another study shows that the mechanism of entry of R9 in HeLa cells depends on the peptide concentration and the availability of alternative endocytic routes (Duchardt et al. 2007). At low concentrations (below $10 \mu \mathrm{M}$ ) R9 is taken up by cells via endocytosis and predominantly localized within vesicles in cytoplasm. At high concentrations, uptake occurs primarily by a highly efficient nonendocytic pathway, leading to a rapid entry of the peptide into the cytoplasm and nucleus (Duchardt et al. 2007). Most recently an energy-independent translocation mechanism for guanidinium-rich molecules has been proposed that relies on two universal cell components: fatty acids and the plasma membrane $\mathrm{pH}$ gradient (Herce et al. 2014). At higher $\mathrm{pH}$ of extracellular environment, fatty acids bind with high affinity to arginine-rich peptides and mediate their membrane transport. In the lower $\mathrm{pH}$ environment of the cytosol, the binding affinity drops and arginine-rich peptides are released inside the cell. This study showed that arginine had a higher affinity for fatty acids than lysine, which explained the unique ability of polyarginine peptides to enter cells so efficiently (Herce et al. 2014). A systematic study showed that longer spacing between the arginine side chains improved the uptake of these carrier peptides (Rothbard et al. 2002). The best cellular uptake was observed for a fully spaced compound with six spacers, one between each of the seven arginines. Molecular modeling showed that such spacing allowed guanidines to park more closely and interact with the putative negative charges that are closely spaced on the cell surface (Rothbard et al. 2002). 
While our experiments provide some insight into PNA uptake, we do not have direct evidence for the potential internalization mechanism of M-modified PNA constructs. The presence of endocytic vesicles supports endocytotic mechanism of entry at both 1 and $10 \mu \mathrm{M}$ PNA concentrations. The results at $1 \mu \mathrm{M}$ concentration of $\mathrm{M}$-modified PNA are consistent with PNA sequestration in acidic endosomal/lysosomal compartments. The observed release of fluorescence from the vesicles at $10 \mu \mathrm{M}$ concentration may be explained either by the "proton sponge" effect (Midoux et al. 2009; Liang and Lam 2012) of 2-aminopyridines or a switch to a nonendocytic uptake mechanism. 2-Aminopyridine is a weak base with $\mathrm{p} K_{\mathrm{a}} \sim 6.7$. In the extracellular medium $(\mathrm{pH}$ 7.2-7.4) only about $20 \%$ of 2 -aminopyridines would be protonated. When PNA is endocytosed, the $\mathrm{pH}$ drops from neutral to $\mathrm{pH} 5-6$ in endosomes and later becomes $\mathrm{pH} 4.5$ in lysosomes. At such acidic $\mathrm{pH}$ 2-aminopyridines will become protonated and will buffer acidification of endosomes. As a result, the membrane-bound ATPase proton pumps will translocate more protons from the cytosol into the endosomes while attempting to lower the $\mathrm{pH}$. This process will be followed by passive entry of chloride ions, increasing ionic concentration and hence water influx. Subsequent endosomal swelling and rupture will lead to a release of endosomal content to the cytosol (Midoux et al. 2009; Liang and Lam 2012). At high concentrations the $\mathrm{pH}$-buffering effect of M-modified PNA constructs is expected to be more pronounced as more PNAs are being membrane-bound and endocytosed.

An alternative explanation may be a switch to a nonendocytic uptake mechanism, as discussed for CPP-PNA conjugates above. Protonated 2-aminopyridine nucleobase modifications resemble protonated guanidinium groups that are spaced along a flexible PNA backbone (for structural similarity, see Fig. 1E). The surprising discovery that $\mathrm{M}$ modifications increase the cellular uptake of PNAs may be explained by such structural similarity that may allow uptake of M-modified PNAs via pathways similar to those of polyarginine CPPs. Interestingly, coadministration of the lysosomotropic reagent chloroquine showed little if any effect on cellular distribution of PNAs (Fig. 6). Although we could not observe localization of PNAs either to the nucleoplasm or to nucleoli even at high concentration, the presence of free PNA in the cytosol may be sufficient for detecting and interfering with biological RNAs located in the cytoplasm. To this end, we have recently demonstrated inhibition of mRNA translation by PNA-dsRNA triplex formation in vitro and in cells (Endoh et al. 2016).

\section{Conclusions}

Given the infancy of our understanding of the various roles that RNA plays in gene regulation, it is conceivable that triplex-forming PNAs may become a valuable tool for studying biologically relevant double-stranded RNA in live cells.
Herein we demonstrated that M-modified PNAs and their conjugates with lysine and arginine tripeptides formed strong and sequence-selective triple helices with RNA hairpins relatively fast under physiologically relevant conditions. The M-modified PNAs had a unique preference for binding dsRNA; binding to dsDNA of the same sequence was one to two orders of magnitude less favorable. This is important because it enables triple helical recognition of dsRNA in biological systems, which has not been possible with standard PNA compounds. Poor cellular uptake has been a major roadblock for applications of PNA technology. Herein we demonstrate that treatment of HEK293 cells with M-modified PNA-peptide conjugates at $10 \mu \mathrm{M}$ efficiently delivered the cationic PNAs to the cytosol without inducing significant cytotoxicity. The most unexpected finding was that M-modified PNAs without conjugation with cationic peptides were also taken up by HEK293 cells. This finding suggests that M-modified PNAs may be superior to traditional PNA compounds not only in molecular recognition of dsRNA, but also for practical applications that require crossing cellular membranes. Taken together, the strong, fast, and selective RNA binding, promising cellular uptake and relatively low cytotoxicity makes the M-modified PNA-peptide conjugates excellent candidates for a wide range of biomedical applications.

\section{MATERIALS AND METHODS}

\section{Solid-phase PNA synthesis}

All PNA sequences were synthesized using a standard 2- $\mu \mathrm{mol}$ scale Fmoc protocol on an Expedite 8909 DNA synthesizer using NovaSyn TG Sieber resin support, as previously reported (Hnedzko et al. 2014). T-PNA-monomer, C(Bhoc)-PNAmonomer, and Fmoc-AEEA spacer were purchased from Link Technologies; Fmoc-Lys(Boc)-OH and Fmoc-Arg(Pbf)-OH were purchased from NovaBiochem; M(Boc)-PNA-monomer was synthesized as previously reported (Zengeya et al. 2012; Hnedzko et al. 2014).

\section{Labeling with HiLyte Fluor 488}

HF488 carboxylic acid was purchased from AnaSpec. After deprotection of the terminal amino group, the resin with the completed PNA sequence was washed with DMF and dried with a stream of $\mathrm{N}_{2}$ gas. Activated dye solution was prepared by vortexing $12.5 \mu \mathrm{L}$ of $0.3 \mathrm{M}$ 2,6-lutidine in DMF, $12 \mu \mathrm{L}$ of $0.19 \mathrm{M}$ HATU in DMF, $7.6 \mu \mathrm{L}$ of $0.33 \mathrm{M}$ dye in $\mathrm{DMF}$, and $18 \mu \mathrm{L}$ of $\mathrm{DMF}$ in a vial with silicon septum for $3 \mathrm{~min}$. The vial was wrapped in aluminum foil to protect the dye from light. A (26-30)-gauge needle was used to inject the reaction mixture through the filter into the middle of the column. Two 1-mL polyethylene syringes were attached to the opposite sides of the column and the assembly was vortexed overnight. The column was washed thoroughly with DMF before deprotection. 


\section{PNA deprotection, purification, and quantification}

The resin was treated with $0.6 \mathrm{~mL}$ of $20 \%(\mathrm{v} / \mathrm{v}) \mathrm{m}$-cresol in TFA for $2 \mathrm{~h}$ to cleave the PNA from the resin. Polyethylene syringes $(1 \mathrm{~mL})$ attached to each end were used to agitate the resin every $30 \mathrm{~min}$. The cleavage solution was collected and separated into three $2-\mathrm{mL}$ vials. An additional $0.2 \mathrm{~mL}$ of the cleavage solution was used to wash the column for $15 \mathrm{~min}$, which was collected into another $2-\mathrm{mL}$ vial. Anhydrous diethyl ether $(\sim 1.5 \mathrm{~mL})$ was added into each vial, and samples were mixed vigorously. The vials were centrifuged for 30 min at 14,500 rpm. Pellets of PNA were dissolved in HPLC-grade water (or $10 \%$ acetonitrile in water) and combined into one vial. The PNA was purified by reverse-phase HPLC with detection at $254 \mathrm{~nm}$. The major peak was collected and the sample was concentrated. The concentration of PNA was determined from UV absorbance at $260 \mathrm{~nm}$. The molar extinction coefficient $\left(\varepsilon_{260} \mathrm{M}^{-1} \mathrm{~cm}^{-1}\right)$ was calculated by summing up the individual extinction coefficients of the monomers and dye: 8560 for T, 2212 for M, 7100 for C, and 26170 for HF488. The identity of the PNAs was confirmed by MALDI TOF mass spectrometry.

Isothermal titration calorimetry (ITC) experiments were done on a MicroCal iTC200 instrument using physiological phosphate buffer ( $2 \mathrm{mM} \mathrm{MgCl}_{2}, 90 \mathrm{mM} \mathrm{KCl}, 10 \mathrm{mM} \mathrm{NaCl}, 50 \mathrm{mM}$ potassium phosphate $[\mathrm{pH} 7.4])$ at $25^{\circ} \mathrm{C}$. Aliquots $(2.49 \mu \mathrm{L})$ of a $90 \mu \mathrm{M}$ PNA solution were sequentially injected from a $40 \mu \mathrm{L}$ rotating syringe (750 rmp) into $200 \mu \mathrm{L}$ of a $10 \mu \mathrm{M}$ RNA hairpin solution. The duration of each injection was $4.98 \mathrm{sec}$ and the delay between injections was 350-650 sec depending on the kinetics of binding.

Florescence spectroscopy and binding kinetics experiments were done on a Shimadzu RF-5301PC spectrofluorophotometer equipped with a rapid-mixing stopped-flow accessory SFA-20 (HiTech Scientific). Equal volumes of $0.1 \mu \mathrm{M}$ PNA 3-HF488 and 1 $\mu \mathrm{M}$ HRP 2-BHQ1 in $50 \mathrm{mM}$ potassium phosphate buffer $(\mathrm{pH}$ 7.4), containing $2 \mathrm{mM} \mathrm{MgCl}_{2}, 90 \mathrm{mM} \mathrm{KCl}$, and $10 \mathrm{mM} \mathrm{NaCl}$, were rapidly mixed from separate syringes in a $1 \mathrm{~cm}$ path-length stopped-flow cuvette at $25^{\circ} \mathrm{C}$. The change in HiLyte Fluor 488 fluorescence emission was monitored at $528 \mathrm{~nm}$ ( $5 \mathrm{~mm}$ slit width) after excitation at $501 \mathrm{~nm}$ (5 mm slit width). The fluorescence decay curves were transformed into $F_{\mathrm{t}} / F_{0}(\%)$ versus $t(\mathrm{sec})$ curves and fitted with the following equation using SigmaPlot:

$$
F_{\mathrm{t}} / F_{\mathrm{o}}=F_{\infty}+a \times \exp \left(-k_{\mathrm{obs}} \times t\right),
$$

where $F_{\mathrm{t}}$ is fluorescence intensity at time $t, F_{0}$ is fluorescence intensity at time $0, F_{\infty}$ is fluorescence intensity at infinity, a is amplitude, $k_{\text {obs }}$ is the observed rate constant, and $t$ is time in seconds. The second-order association rate constant, $k_{\mathrm{on}}$, can be calculated as $k_{\mathrm{obs}}=$ $k_{\text {on }}[\mathrm{RNA}]+k_{\text {off, }}$ where [RNA] is the concentration of HRP 2-BHQ1 and $k_{\text {off }}$ is the dissociation rate constant. The kinetics of triplex formation was studied at $25^{\circ} \mathrm{C}$, the temperature where the equilibrium is completely shifted to triplex formation. Following the approach described by Xodo (1995), we can assume that $k_{\text {off }}$ is approximately zero and calculate $k_{\text {on }}=k_{\text {obs }} /[\mathrm{RNA}]$. The final $k_{\text {obs }}$ and $k_{\text {on }}$ values were obtained as an average of five independent measurements.

\section{Flow cytometry}

HEK293 cells $\left(1 \times 10^{6}\right.$ cells/well $)$ were plated on a 24 -well plate in $10 \%$ fetal bovine serum Dulbecco's modified Eagle's medium (FBS-DMEM) and incubated overnight at $37^{\circ} \mathrm{C}, 10 \% \mathrm{CO}_{2}$. The medium was discarded and cells were washed with OptiMEM (no FBS) followed by incubation with $1 \mu \mathrm{M}$ PNA in OptiMEM for different lengths of time. Following incubation, cells were harvested and resuspended in $1 \mathrm{~mL}$ of Dulbecco's phosphate-buffered saline (DPBS) to run on a FACSCalibur flow cytometer. For each experiment, cells that were not incubated with PNA were also analyzed as a control. The data table represents a mean of three independent experiments \pm SE.

\section{Confocal microscopy}

HEK293 cells $\left(15 \times 10^{3}\right)$ were plated on an 8-well Lab-Tek chambered coverglass (precoated with Collagen I) in 10\% FBS-DMEM and cultured overnight. The medium was discarded and cells were washed with OptiMEM (no FBS) followed by incubation with 300 $\mu \mathrm{L}$ of $1 \mu \mathrm{M}$ PNA-HF488 conjugate in OptiMEM (or $1 \mu \mathrm{M}$ PNAHF488 conjugate/100 $\mu \mathrm{M}$ chloroquine in OptiMEM) for $24 \mathrm{~h}$ at $37^{\circ} \mathrm{C}, 10 \% \mathrm{CO}_{2}$. After incubation, cells were washed with OptiMEM twice before addition of $300 \mu \mathrm{L}$ of $65 \mathrm{nM}$ LysoTracker Deep Red to stain acidic organelles (red) and $50 \mu \mathrm{g} / \mathrm{mL} 4^{\prime}, 6$-diamidino-2-phenylindole (DAPI) to stain the nuclear DNA (blue) into each well and incubated for $1 \mathrm{~h}$. After two washes, $300 \mu \mathrm{L}$ of OptiMEM (without phenol red) medium containing HEPES buffer was added into the wells for observation of living cells. Uptake of HF488-labeled PNAs was detected as green fluorescence measured at $488 \mathrm{~nm}$. The images were acquired using an inverted Axiovert Zeiss Laser Scanning Microscope 510 using a $63 \times$ objective. When comparing the uptake of the PNA conjugates, the imaging conditions (such as photomultiplier gain/offset, laser intensities, and confocal aperture size) were kept constant for the observation of the different conjugates, so that the intensities represent true differences in uptake.

\section{Cytotoxicity}

The XTT proliferation assay was used to measure cell proliferation by comparing relative absorbance to a control that contained no PNA. HEK293 cells $\left(2 \times 10^{4}\right.$ cells/well $)$ were plated on a 96-well plate in $10 \%$ FBS-DMEM and incubated overnight at $37^{\circ} \mathrm{C}, 10 \%$ $\mathrm{CO}_{2}$. The medium was discarded and cells were treated with different concentrations of PNA in OptiMEM ( no FBS). Following $22 \mathrm{~h}$ of incubation, Activated-XTT was added and cells were incubated for an additional $2 \mathrm{~h}$. A plate reader was used to measure absorbance at a wavelength of $450 \mathrm{~nm}$ minus the absorbance at $650 \mathrm{~nm}$ after the incubation period.

\section{SUPPLEMENTAL MATERIAL}

Supplemental material is available for this article.

\section{ACKNOWLEDGMENTS}

This work was supported by the National Science Foundation (CHE-1406433, CHE-0922815 to E.R.) and National Institutes of Health (R01 GM071461 to E.R.). We thank Dr. Christof Grewer for the generous gift of HEK293 cells and undergraduate students Derek Orshan, Ian Anderson, Brian Cuzzo, and Andrea Wolf for their help with synthesis of PNAs.

Received July 22, 2016; accepted October 8, 2016. 


\section{REFERENCES}

Abes S, Williams D, Prevot P, Thierry A, Gait MJ, Lebleu B. 2006. Endosome trapping limits the efficiency of splicing correction by PNA-oligolysine conjugates. J Control Release 110: 595-604.

Alberti P, Arimondo PB, Mergny J-L, Garestier T, Helene C, Sun J-S. 2002. A directional nucleation-zipping mechanism for triple helix formation. Nucleic Acids Res 30: 5407-5415.

Annoni C, Endoh T, Hnedzko D, Rozners E, Sugimoto N. 2016. Triplexforming peptide nucleic acid modified with 2-aminopyridine as a new tool for detection of A-to-I editing. Chem Commun 52: 7935-7938.

Bartel DP. 2004. MicroRNAs: genomics, biogenesis, mechanism, and function. Cell 116: 281-297.

Bartel DP. 2009. MicroRNAs: target recognition and regulatory functions. Cell 136: 215-233.

Bates PJ, Laughton CA, Jenkins TC, Capaldi DC, Roselt PD, Reese CB, Neidle S. 1996. Efficient triple helix formation by oligodeoxyribonucleotides containing $\alpha$ - or $\beta$-2-amino-5-(2-deoxy-D-ribofuranosyl) pyridine residues. Nucleic Acids Res 24: 4176-4184.

Bonnet E, Wuyts J, Rouze P, Van de Peer Y. 2004. Evidence that microRNA precursors, unlike other non-coding RNAs, have lower folding free energies than random sequences. Bioinformatics 20: 2911-2917.

Chow CS, Bogdan FM. 1997. A structural basis for RNA-ligand interactions. Chem Rev 97: 1489-1513.

Cruz JA, Westhof E. 2009. The dynamic landscapes of RNA architecture. Cell 136: 604-609.

Devi G, Zhou Y, Zhong Z, Toh D-FK, Chen G. 2015. RNA triplexes: from structural principles to biological and biotech applications. Wiley Interdiscip Rev RNA 6: 111-128.

Duchardt F, Fotin-Mleczek M, Schwarz H, Fischer R, Brock R. 2007. A comprehensive model for the cellular uptake of cationic cell-penetrating peptides. Traffic 8: 848-866.

Dunham I, Kundaje A, Aldred SF, Collins PJ, Davis CA, Doyle F, Epstein CB, Frietze S, Harrow J, Kaul R, et al. 2012. An integrated encyclopedia of DNA elements in the human genome. Nature 489: 57-74.

Endoh T, Hnedzko D, Rozners E, Sugimoto N. 2016. Nucleobase-modified PNA suppresses translation by forming a triple helix with a hairpin structure in mRNA in vitro and in cells. Angew Chem Int Ed Engl 55: 899-903.

Escude C, Francois JC, Sun JS, Ott G, Sprinzl M, Garestier T, Helene C. 1993. Stability of triple helixes containing RNA and DNA strands: experimental and molecular modeling studies. Nucleic Acids Res 21: $5547-5553$.

Fabani MM, Gait MJ. 2008. miR-122 targeting with LNA/2'-O-methyl oligonucleotide mixmers, peptide nucleic acids (PNA), and PNApeptide conjugates. RNA 14: 336-346.

Fabani MM, Abreu-Goodger C, Williams D, Lyons PA, Torres AG, Smith KGC, Enright AJ, Gait MJ, Vigorito E. 2010. Efficient inhibition of miR-155 function in vivo by peptide nucleic acids. Nucleic Acids Res 38: 4466-4475.

Fuchs SM, Raines RT. 2004. Pathway for polyarginine entry into mammalian cells. Biochemistry 43: 2438-2444.

Han H, Dervan PB. 1993. Sequence-specific recognition of double helical RNA and RNA-DNA by triple helix formation. Proc Natl Acad Sci 90: 3806-3810.

Hansen ME, Bentin T, Nielsen PE. 2009. High-affinity triplex targeting of double stranded DNA using chemically modified peptide nucleic acid oligomers. Nucleic Acids Res 37: 4498-4507.

Herce HD, Garcia AE, Cardoso MC. 2014. Fundamental molecular mechanism for the cellular uptake of guanidinium-rich molecules. J Am Chem Soc 136: 17459-17467.

Hildbrand S, Leumann C. 1996. Enhancing DNA triple helix stability at neutral $\mathrm{pH}$ by the use of oligonucleotides containing a more basic deoxycytidine analog. Angew Chem Int Ed Engl 35: 1968-1970.

Hildbrand S, Blaser A, Parel SP, Leumann CJ. 1997. 5-Substituted 2aminopyridine $\mathrm{C}$-nucleosides as protonated cytidine equivalents: in- creasing efficiency and specificity in DNA triple-helix formation. $J$ Am Chem Soc 119: 5499-5511.

Hnedzko D, Cheruiyot Samwel K, Rozners E. 2014. Using triple-helixforming peptide nucleic acids for sequence-selective recognition of double-stranded RNA. Curr Protoc Nucleic Acid Chem 58: 4.60.164.60.23.

Hnedzko D, McGee DW, Rozners E. 2016. Synthesis and properties of peptide nucleic acid labeled at the N-terminus with HiLyte Fluor 488 fluorescent dye. Bioorg Med Chem 24: 4199-4205.

$\mathrm{Hu}$ J, Corey DR. 2007. Inhibiting gene expression with peptide nucleic acid (PNA)-peptide conjugates that target chromosomal DNA. Biochemistry 46: 7581-7589.

Hu J, Matsui M, Gagnon KT, Schwartz JC, Gabillet S, Arar K, Wu J, Bezprozvanny I, Corey DR. 2009. Allele-specific silencing of mutant huntingtin and ataxin-3 genes by targeting expanded CAG repeats in mRNAs. Nat Biotechnol 27: 478-484.

Koppelhus U, Nielsen PE. 2003. Cellular delivery of peptide nucleic acid (PNA). Adv Drug Deliv Rev 55: 267-280.

Lee Y, Jeon K, Lee J-T, Kim S, Kim VN. 2002. MicroRNA maturation: stepwise processing and subcellular localization. EMBO $J$ 21: 4663-4670.

Lescoute A, Westhof E. 2006. The interaction networks of structured RNAs. Nucleic Acids Res 34: 6587-6604.

Li M, Zengeya T, Rozners E. 2010. Short peptide nucleic acids bind strongly to homopurine tract of double helical RNA at $\mathrm{pH} 5.5 . \mathrm{J}$ Am Chem Soc 132: 8676-8681.

Liang W, Lam JKW. 2012. Endosomal escape pathways for non-viral nucleic acid delivery systems. In Molecular regulation of endocytosis (ed. Ceresa B). InTech, doi: 10.5772/46006.

Ling H, Fabbri M, Calin GA. 2013. MicroRNAs and other non-coding RNAs as targets for anticancer drug development. Nat Rev Drug Discov 12: 847-865.

Madani F, Lindberg S, Langel U, Futaki S, Graeslund A. 2011. Mechanisms of cellular uptake of cell-penetrating peptides. $J$ Biophys 2011: 414729.

Mercer TR, Mattick JS. 2013. Structure and function of long noncoding RNAs in epigenetic regulation. Nat Struct Mol Biol 20: 300-307.

Midoux P, Pichon C, Yaouanc J-J, Jaffres P-A. 2009. Chemical vectors for gene delivery: a current review on polymers, peptides and lipids containing histidine or imidazole as nucleic acids carriers. $\mathrm{Br} \mathrm{J}$ Pharmacol 157: 166-178.

Mitchell DJ, Kim DT, Steinman L, Fathman CG, Rothbard JB. 2000. Polyarginine enters cells more efficiently than other polycationic homopolymers. J Pept Res 56: 318-325.

Muse O, Zengeya T, Mwaura J, Hnedzko D, McGee DW, Grewer CT, Rozners E. 2013. Sequence selective recognition of double-stranded RNA at physiologically relevant conditions using PNA-peptide conjugates. ACS Chem Biol 8: 1683-1686.

Quarles KA, Sahu D, Havens MA, Forsyth ER, Wostenberg C, Hastings ML, Showalter SA. 2013. Ensemble analysis of primary microRNA structure reveals an extensive capacity to deform near the Drosha cleavage site. Biochemistry 52: 795-807.

Roberts RW, Crothers DM. 1992. Stability and properties of double and triple helices: dramatic effects of RNA or DNA backbone composition. Science 258: 1463-1466.

Rothbard JB, Kreider E, VanDeusen CL, Wright L, Wylie BL, Wender PA. 2002. Arginine-rich molecular transporters for drug delivery: role of backbone spacing in cellular uptake. J Med Chem 45: 3612-3618.

Rozners E. 2013. Recent advances in chemical modification of peptide nucleic acids. J Nucleic Acids 518162.

Sahu B, Chenna V, Lathrop KL, Thomas SM, Zon G, Livak KJ, Ly DH. 2009. Synthesis of conformationally preorganized and cell-permeable guanidine-based $\gamma$-peptide nucleic acids ( $\gamma$ GPNAs). J Org Chem 74: 1509-1516.

Shiraishi T, Nielsen PE. 2006. Enhanced delivery of cell-penetrating peptide-peptide nucleic acid conjugates by endosomal disruption. Nat Protoc 1: 633-636. 
Turner JJ, Ivanova GD, Verbeure B, Williams D, Arzumanov AA, Abes S, Lebleu B, Gait MJ. 2005. Cell-penetrating peptide conjugates of peptide nucleic acids (PNA) as inhibitors of HIV-1 Tat-dependent trans-activation in cells. Nucleic Acids Res 33: 6837-6849.

Wancewicz EV, Maier MA, Siwkowski AM, Albertshofer K, Winger TM, Berdeja A, Gaus H, Vickers TA, Bennett CF, Monia BP, et al. 2011. Peptide nucleic acids conjugated to short basic peptides show improved pharmacokinetics and antisense activity in adipose tissue. $J$ Med Chem 53: 3919-3926.

Wittung P, Kajanus J, Edwards K, Nielsen P, Norden B, Malmstroem BG. 1995. Phospholipid membrane permeability of peptide nucleic acid. FEBS Lett 365: 27-29.
Xodo LE. 1995. Kinetic analysis of triple-helix formation by pyrimidine oligodeoxynucleotides and duplex DNA. Eur JBiochem 228: 918-926.

Zengeya T, Gupta P, Rozners E. 2012. Triple helical recognition of RNA using 2-aminopyridine-modified PNA at physiologically relevant conditions. Angew Chem Int Ed Engl 51: 12593-12596.

Zhou P, Wang M, Du L, Fisher GW, Waggoner A, Ly DH. 2003. Novel binding and efficient cellular uptake of guanidine-based peptide nucleic acids (GPNA). J Am Chem Soc 125: 6878-6879.

Zhou Y, Kierzek E, Loo ZP, Antonio M, Yau YH, Chuah YW, GeifmanShochat S, Kierzek R, Chen G. 2013. Recognition of RNA duplexes by chemically modified triplex-forming oligonucleotides. Nucleic Acids Res 41: 6664-6673. 

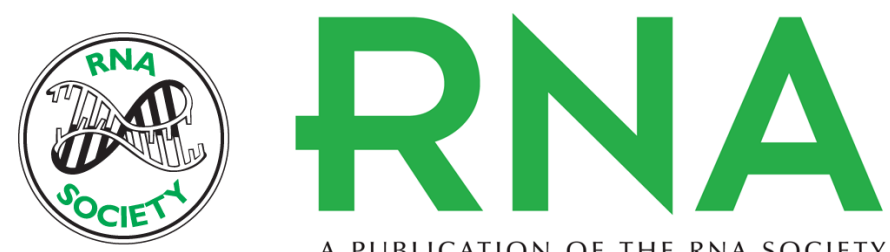

A PUBLICATION OF THE RNA SOCIETY

\title{
Sequence-selective recognition of double-stranded RNA and enhanced cellular uptake of cationic nucleobase and backbone-modified peptide nucleic acids
}

\author{
Dziyana Hnedzko, Dennis W. McGee, Yannis A. Karamitas, et al.
}

RNA 2017 23: 58-69 originally published online October 14, 2016

Access the most recent version at doi:10.1261/rna.058362.116

Supplemental Material

References

Creative Commons License

Email Alerting Service
http://rnajournal.cshlp.org/content/suppl/2016/10/14/rna.058362.116.DC1

This article cites 49 articles, 4 of which can be accessed free at: http://rnajournal.cshlp.org/content/23/1/58.full.html\#ref-list-1

This article is distributed exclusively by the RNA Society for the first 12 months after the full-issue publication date (see http://rnajournal.cshlp.org/site/misc/terms.xhtml). After 12 months, it is available under a Creative Commons License (Attribution-NonCommercial 4.0 International), as described at http://creativecommons.org/licenses/by-nc/4.0/.

Receive free email alerts when new articles cite this article - sign up in the box at the top right corner of the article or click here.

\section{|||||||| Providing Precise Solutions for} your research.

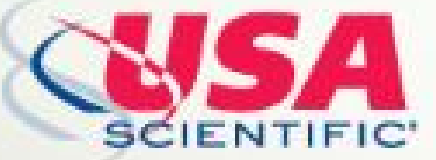

To subscribe to $R N A$ go to:

http://rnajournal.cshlp.org/subscriptions 